Military Technical College

Kobry Elkobbah,

Cairo, Egypt

April 19-21,2016

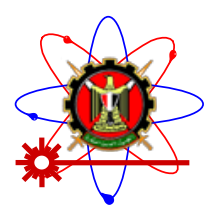

$8^{\text {th }}$ International Conference on Mathematics and Engineering Physics (ICMEP-8)

\title{
EM-8
}

\section{Mine Detector Selection Using Multiple Criteria Decision Making Techniques}

\author{
By \\ Mohamed Hassan * \\ Aly Ragab ${ }^{\dagger}$ \\ Gouda Mohamed ${ }^{\ddagger}$
}

\begin{abstract}
The weapon selection problem is a strategic issue and has a significant impact on the efficiency of defense systems. Selecting a weapon among many alternatives is a multiple criteria decision making (MCDM) problem. MCDM is made of stepwise procedures useful for complex problems allowing to rank the overall performances of a finite set of alternatives in respect to certain criteria of interest. They help the Decision Maker (DM) to identify the (best) feasible solution which is defined as the one which more closely matches all the relevant goals. In this paper,seven discrete MCDM methods are used to solve the mine detector selection problem to be used in the Egyptian Armed Forces. Spearman's rank correlation test is used to determinethe degree to which the methods are related.
\end{abstract}

\section{Keywords:}

Multiple criteria decision making methods,mine detector selection,Spearman's rank correlation test.

\section{Introduction}

One of the most important components of a country's nationalpower is military power and The Armed Forces is the applicationinstrument of deterrent military power. Acquisitionof the mine detector satisfying the performance, cost and usability requirements are critical

\footnotetext{
* Corresponding author: Military Technical College, Cairo, Egypt. E-mail: mohamed.s.m.hassan@hotmail.com, 01062633469.

${ }^{\dagger}$ Department of Operations Research, Institute of Statistical Studies and Research, Cairo University, Giza, Egypt.

${ }^{\ddagger}$ Military Technical College, Cairo, Egypt.
} 
Military Technical College

Kobry Elkobbah,

Cairo, Egypt

April 19-21,2016

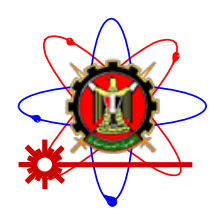

factorseffect on the efficiency of World's Armed Forceswhich carry out operations in both war and peace.

The past researchers have successfully appliedvarious MCDM approaches for making thebest decisions for different engineering applications and military application.R. Mohanty [1], used AHP to assist in the selection of project proposals.M. Janic and A. Reggiani[2], used MCDM methods (SAW, TOPSIS and AHP) to the problem of the selection of a new hub airport for a hypothetical European Union (EU) airline assumed to operate within the EU liberalized air transport market.N. Caterino, I. Iervolino, G. Manfredi, and E. Cosenza [3], used TOPSIS method for the choice of the best seismic retrofit solution for an under-designed RC structure.P. Yanpirat and V. Panjarongkha[4], used AHP as a ranking method for the group decision-making of site selection for water fabrication plant in Thailand.G. Yang, W. J. Huang, and L. L. Lei [5], used an integrated framework is proposed to approach the supplier selection problem in NPP supply chain systems utilizing AHP and improved TOPSIS.K. R. Gaurh, I. Khan, and M. Ghosh [6], utilized AHP and TOPSIS Method for solving the quandary of Material Handling Equipment cull in different shops of automobile industry.A. Kahriman, M. Oztokatli, and G. S. Das [7], utilized two of the most commonly used multi criteria decision making methods namely Analytic AHP and TOPSIS to select the most suitable communication satellite manufacturer.D. S. Resobowo, K. A. Buda, and A. Dinariyana[8], used AHP as it is implemented in the software package Expert Choice to select multiple variables that affect the military ship's maintenance. T.-H. Chang and T.-C. Wang [9], used TOPSIS to choose optimal initial training aircraft.M. Dağdeviren, S. Yavuz, and N. Kılınç[10], used AHP to analyze the structure of the weapon selection problem and to determine weights of the criteria, and TOPSIS method is used to obtain final ranking.

In this paper, seven discrete MCDM methods(Max-Min, Max-Max, SAW, WPM, ELECTRE, TOPSIS, and AHP) are chosen to deal with the problem of selecting Mine detector. Each one reflects a different approach to solve MCDM problems. All seven methods require the pre-selection of a countable number of alternatives with respect to a countable number of criteria.

\section{Methods}

The paper introduces a brief description about MCDM and covers seven of the practical methods (Max-Min, Max-Max, SAW, WPM, ELECTRE, TOPSIS, and AHP).These methods have shown to be popular and widely used by researchers.MCDM is an application of Operations Research;MCDM methods are available for helping make better decisions for decision problems, which often exhibit these characteristics: the presence of multiple, conflicting criteria for judging the alternatives and the need for making compromises or tradeoffs regarding the outcomes of alternate courses of action.

A common problem in MCDM with the use of different units [11] of evaluation measures. This issue can be addressed by "normalization". There are different methods of normalization according to each method.Many MCDM methods require the use of relative importance weights of criteria [11].

An alternative is dominated if there is another alternative, which exceeds it in one or more attributes and equals it in the remainder. The number of alternatives can be reduced by 
Military Technical College

Kobry Elkobbah,

Cairo, Egypt

April 19-21,2016

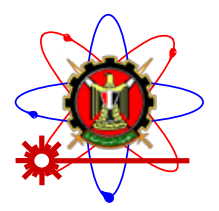

eliminating the dominated ones "dominance check". In other words we screen the set of alternatives before the final choice is made. A set of non-dominated solutions is one obtained through the sieve of dominance method.

Max-Min methodis based on the assumption that the DM has a pessimistic nature[12]. DM would examine the attribute values for each alternative, note the lowest value for each alternative, and then select the alternative with the most acceptable value in its lowest attribute.

Max-Max methodis in contrast to the Max-Min method DM has an optimistic nature[12]. Max-Max method selects an alternate by its best attribute value rather than its worst attribute value.

Simple Additive Weighting method (SAW) is probably the best known and very widely used method of MCDM [12].

Weighted product methodis almost similar to SAW method [13]. In SAW method, there is addition of the weighted normalized criteria values,but in WPM method, the normalized criteria values are multiplied.

Elimination Et Choice Translating Reality (ELECTRE) method falls under the category called outranking methods [2]. It compares two alternatives at a timeand attempts to build an outranking relationship to eliminate alternatives that are dominated using the outranking relationship.

TOPSIS (technique for order preference by similarity to ideal solution) was originally proposed by Hwang and Yoon[12]. TOPSIS operates on the principle that the preferred solution (alternative) should simultaneously be closest to the ideal solution, $\mathrm{H}^{*}$, and farthest from the negative-ideal solution, $\mathrm{L}^{*}$.

The analytic hierarchy process (AHP) is a technique developed by Camm and Evans[14] for solving complex problems involving multiple criteria. The process requires the decision maker to provide judgments about the relative importance of each criterion and then specify a preference on each criterion for each decision alternative.

\section{Case Study}

Seven discrete MCDM methods, Max-Min, Max-Max, SAW, WPM, ELECTRE, TOPSIS, and AHPare applied on a real problem of selecting mine detector.All seven methods require the pre-selection of four alternatives with respect to ten criteria. We use Microsoft excel sheets [15], [16] in solving our problem according to the different methods. We can summarize the data in table (1). 
Military Technical College

Kobry Elkobbah,

Cairo, Egypt

April 19-21,2016

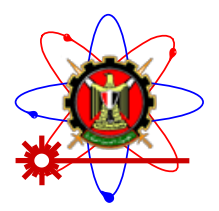

$8^{\text {th }}$ International Conference on Mathematics and Engineering Physics (ICMEP-8)

Table 1. Problem data

\begin{tabular}{|c|c|c|c|c|}
\hline $\begin{array}{c}\text { Alternatives } \\
\text { Criteria }\end{array}$ & $A_{1}$ & $A_{2}$ & $A_{3}$ & $A_{4}$ \\
\hline$C_{1}$ & 4 & 3.5 & 4 & 6 \\
\hline$C_{2}$ & 60 & 55 & 63 & 68 \\
\hline$C_{3}$ & 6 & 8 & 4 & 5 \\
\hline$C_{4}$ & 92 & 75 & 81 & 83 \\
\hline$C_{5}$ & 559 & 309 & 210 & 600 \\
\hline$C_{6}$ & 30 & 8 & 15 & 20 \\
\hline$C_{7}$ & 1.5 & 0.9 & 0.5 & 0.3 \\
\hline$C_{8}$ & 1 & 4.5 & 2 & 3 \\
\hline$C_{9}$ & 9 & 9 & 7 & 5 \\
\hline$C_{10}$ & 9 & 7 & 5 & 5 \\
\hline
\end{tabular}

A common problem in MCDM is the use of different units for evaluation, so we make normalization to convert all the measurements in a common scale. We also check the dominance between the alternatives. There is no dominated alternative by other alternatives to eliminate it. The four alternatives are used in our calculations. Tables (2), (3), and (4) show the normalization matrix for the different methods.

The weights of criteria are determined using pairwise comparison matrix as shown in table (5). We get information by asking the specialists in this field. We get the weights and the consistency ratio of the pairwise comparative judgments as shown in table (6). Since CR is less than 0.1 , this value is acceptable and indicates good consistency of the pairwise comparative judgments. 
Military Technical College

Kobry Elkobbah,

Cairo, Egypt

April 19-21,2016

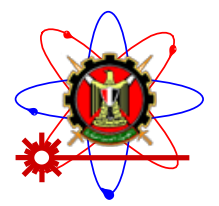

$8^{\text {th }}$ International Conference on Mathematics and Engineering Physics (ICMEP-8)

Table 2. Normalization matrix for (Max-Min, Max-Max, SAW, and WPM)

\begin{tabular}{|c|c|c|c|c|c|c|c|c|c|c|}
\hline Criteria & \multirow{2}{*}{$C_{1}$} & $C_{2}$ & $C_{3}$ & $C_{4}$ & $C_{5}$ & $C_{6}$ & $C_{7}$ & $C_{8}$ & $C_{9}$ & $C_{10}$ \\
\hline \multicolumn{1}{|c|}{} & & & & & & & & & & \\
\hline$A_{1}$ & 0.87 & 0.91 & 0.75 & 1 & 0.93 & 1 & 1 & 0.22 & 1 & 1 \\
\hline$A_{2}$ & 1 & 1 & 1 & 0.81 & 0.51 & 0.26 & 0.6 & 1 & 1 & 0.77 \\
\hline$A_{3}$ & 0.87 & 0.87 & 0.5 & 0.88 & 0.35 & 0.5 & 0.33 & 0.44 & 0.77 & 0.55 \\
\hline$A_{4}$ & 0.58 & 0.80 & 0.62 & 0.90 & 1 & 0.66 & 0.2 & 0.66 & 0.55 & 0.55 \\
\hline
\end{tabular}

Table 3. Normalization matrix used for TOPSIS and ELECTRE methods

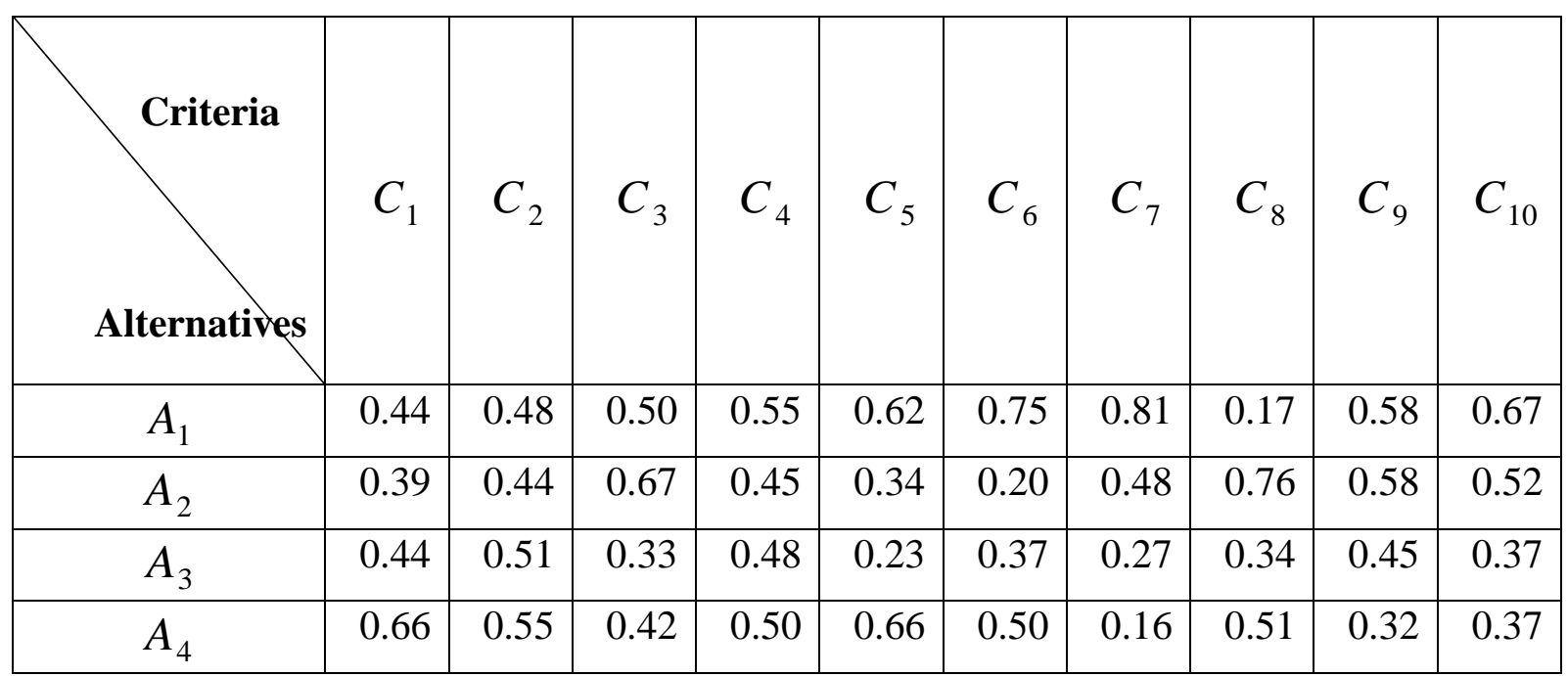


Military Technical College

Kobry Elkobbah,

Cairo, Egypt

April 19-21,2016

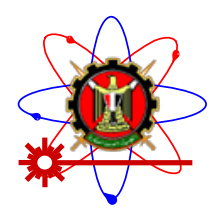

$8^{\text {th }}$ International Conference on Mathematics and Engineering Physics (ICMEP-8)

Table 4. Normalization matrix used for AHP methods

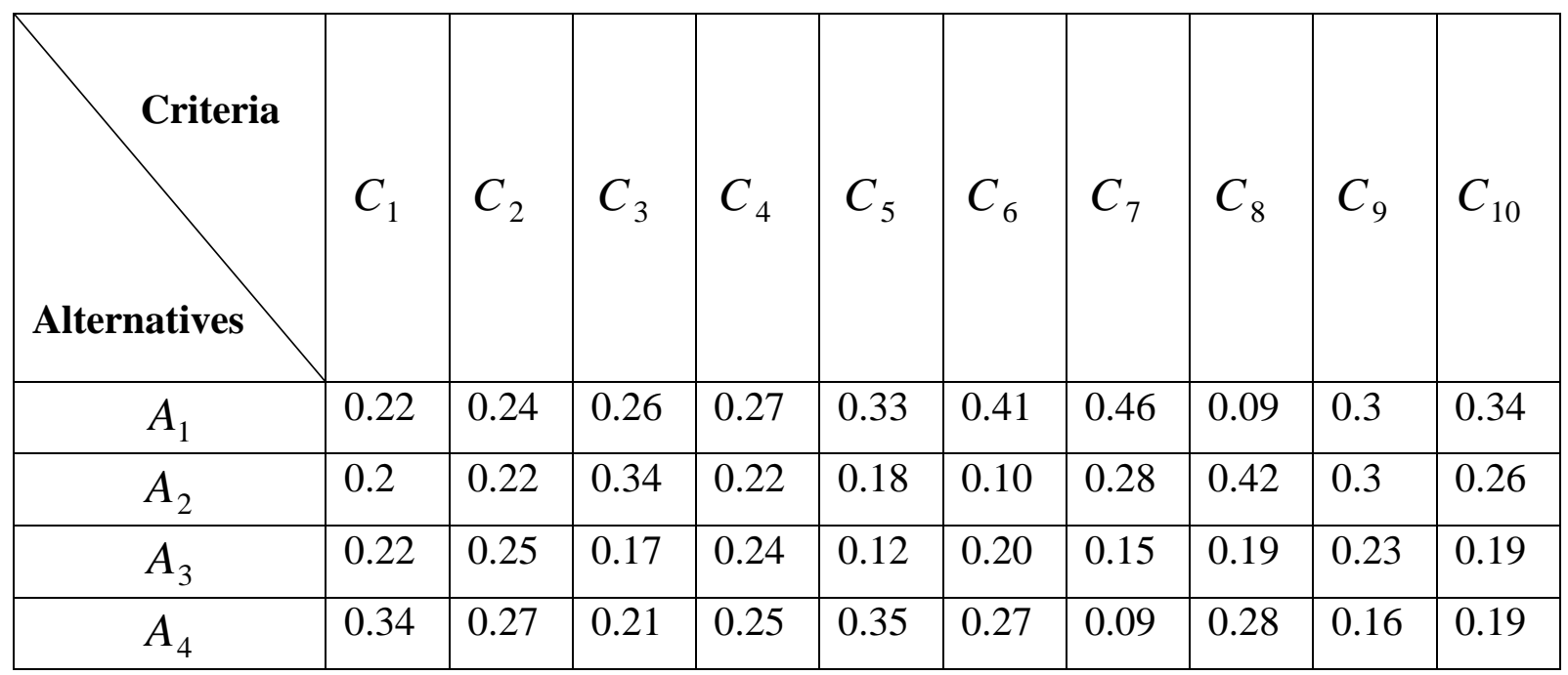

Table 5. Pairwise comparison matrix for criteria weighting

\begin{tabular}{|c|c|c|c|c|c|c|c|c|c|c|}
\hline Criteria & $C_{1}$ & $C_{2}$ & $C_{3}$ & $C_{4}$ & $C_{5}$ & $C_{6}$ & $C_{7}$ & $C_{8}$ & $C_{9}$ & $C_{10}$ \\
\hline$C_{1}$ & 1 & 7 & 5 & 8 & 4 & 3 & 2 & $1 / 2$ & $1 / 2$ & 1 \\
\hline$C_{2}$ & $1 / 7$ & 1 & $1 / 3$ & 3 & $1 / 5$ & $1 / 4$ & $1 / 6$ & $1 / 9$ & $1 / 9$ & $1 / 7$ \\
\hline$C_{3}$ & $1 / 5$ & 3 & 1 & 5 & $1 / 3$ & $1 / 2$ & $1 / 4$ & $1 / 7$ & $1 / 7$ & $1 / 6$ \\
\hline$C_{4}$ & $1 / 8$ & $1 / 3$ & $1 / 5$ & 1 & $1 / 5$ & $1 / 4$ & $1 / 6$ & $1 / 9$ & $1 / 9$ & $1 / 7$ \\
\hline$C_{5}$ & $1 / 4$ & 5 & 3 & 5 & 1 & 2 & $1 / 3$ & $1 / 6$ & $1 / 6$ & $1 / 4$ \\
\hline$C_{6}$ & $1 / 3$ & 4 & 2 & 4 & $1 / 2$ & 1 & $1 / 3$ & $1 / 5$ & $1 / 5$ & $1 / 4$ \\
\hline$C_{7}$ & $1 / 2$ & 6 & 4 & 6 & 3 & 3 & 1 & $1 / 4$ & $1 / 4$ & $1 / 3$ \\
\hline$C_{8}$ & 2 & 9 & 7 & 9 & 6 & 5 & 4 & 1 & 1 & 2 \\
\hline$C_{9}$ & 2 & 9 & 7 & 9 & 6 & 5 & 4 & 1 & 1 & 2 \\
\hline$C_{10}$ & 1 & 7 & 6 & 7 & 4 & 4 & 3 & $1 / 2$ & $1 / 2$ & 1 \\
\hline
\end{tabular}


Military Technical College Kobry Elkobbah,

Cairo, Egypt

April 19-21,2016 $8^{\text {th }}$ International Conference on Mathematics and Engineering Physics (ICMEP-8)

Table 6. Criteria weights and consistency

\begin{tabular}{|c|c|c|}
\hline Criteria & Weight & Consistency Ratio \\
\hline$C_{1}$ & 0.131 & $5 \%$ \\
\hline$C_{2}$ & 0.022 & \\
\hline$C_{3}$ & 0.031 & \\
\hline$C_{4}$ & 0.021 & \\
\hline$C_{5}$ & 0.044 & \\
\hline$C_{6}$ & 0.045 & \\
\hline$C_{7}$ & 0.070 & \\
\hline$C_{8}$ & 0.249 & \\
\hline$C_{9}$ & 0.249 & \\
\hline$C_{10}$ & 0.138 & \\
\hline Sum & 1 & \\
\hline & &
\end{tabular}

\section{Application using Max-Min Method}

As shown in table (7), $A_{3}$ is the best one.

Table 7. Ranking detectors using Max-Min method

\begin{tabular}{|c|c|c|c|c|c|c|c|c|c|c|c|c|c|}
\hline & $C_{1}$ & $C_{2}$ & $C_{3}$ & $C_{4}$ & $C_{5}$ & $C_{6}$ & $C_{7}$ & $C_{8}$ & $C_{9}$ & $C_{10}$ & 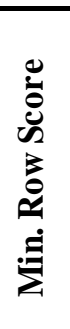 & 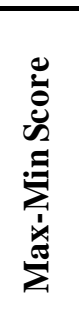 & 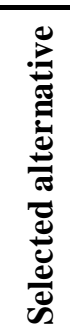 \\
\hline$A_{1}$ & 0.88 & 0.92 & 0.75 & 1.00 & 0.93 & 1.00 & 1.00 & 0.22 & 1.00 & 1.00 & 0.22 & \multirow{4}{*}{0.33} & \multirow{4}{*}{$A_{3}$} \\
\hline$A_{2}$ & 1.00 & 1.00 & 1.00 & 0.82 & 0.52 & 0.27 & 0.60 & 1.00 & 1.00 & 0.78 & 0.27 & & \\
\hline$A_{3}$ & 0.88 & 0.87 & $\begin{array}{l}0.50 \\
\end{array}$ & 0.88 & 0.35 & 0.50 & 0.33 & 0.44 & 0.78 & 0.56 & 0.33 & & \\
\hline$A_{4}$ & 0.58 & 0.81 & 0.63 & 0.90 & 1.00 & 0.67 & 0.20 & 0.67 & 0.56 & 0.56 & 0.20 & & \\
\hline
\end{tabular}

\section{Application using Max-Max Method}

As shown in table (8), $A_{1}, A_{2}, A_{4}$ are the best alternatives. 
Military Technical College

Kobry Elkobbah,

Cairo, Egypt

April 19-21,2016

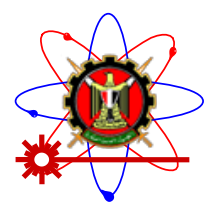

$8^{\text {th }}$ International Conference on Mathematics and Engineering Physics (ICMEP-8)

Table 8. Ranking detectors using Max-Max method

\begin{tabular}{|c|c|c|c|c|c|c|c|c|c|c|c|c|c|}
\hline & $C_{1}$ & $C_{2}$ & $C_{3}$ & $C_{4}$ & $C_{5}$ & $C_{6}$ & $C_{7}$ & $C_{8}$ & $C_{9}$ & $C_{10}$ & 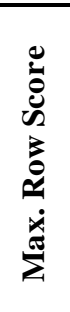 & 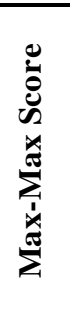 & 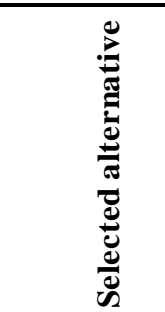 \\
\hline$A_{1}$ & 0.88 & 0.92 & 0.75 & 1.00 & 0.93 & 1.00 & 1.00 & 0.22 & 1.00 & 1.00 & 1.00 & \multirow{4}{*}{1} & \multirow{4}{*}{$A_{1}, A_{2}, A_{4}$} \\
\hline & 1.00 & 1.00 & 1.00 & 0.82 & 0.52 & 0.27 & 0.60 & 1.00 & 1.00 & 0.78 & 1.00 & & \\
\hline$A_{3}$ & 0.88 & 0.87 & 0.50 & 0.88 & 0.35 & 0.50 & 0.33 & 0.44 & 0.78 & 0.56 & 0.88 & & \\
\hline$A_{1}$ & 0.58 & 0.81 & 0.63 & 0.90 & 1.00 & 0.67 & 0.20 & 0.67 & 0.56 & 0.56 & 1.00 & & \\
\hline
\end{tabular}

\section{Application using Simple Additive Weighting Method}

As shown in table (9), $A_{2}$ is the best one.

Table 9. Ranking detectors using SAW method

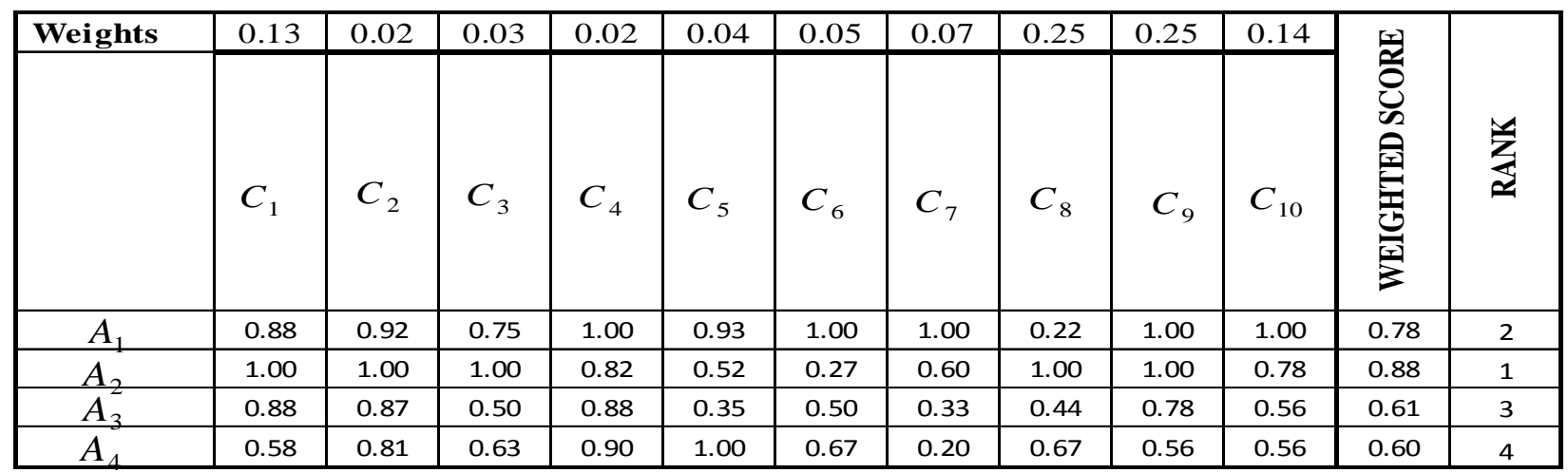

\section{Application using Weighted Product Method}

As shown in table (10), $A_{2}$ is the best one. 
Military Technical College

Kobry Elkobbah,

Cairo, Egypt

April 19-21,2016 $8^{\text {th }}$ International Conference on Mathematics and Engineering Physics (ICMEP-8)

Table 10. Ranking detectors using WPM

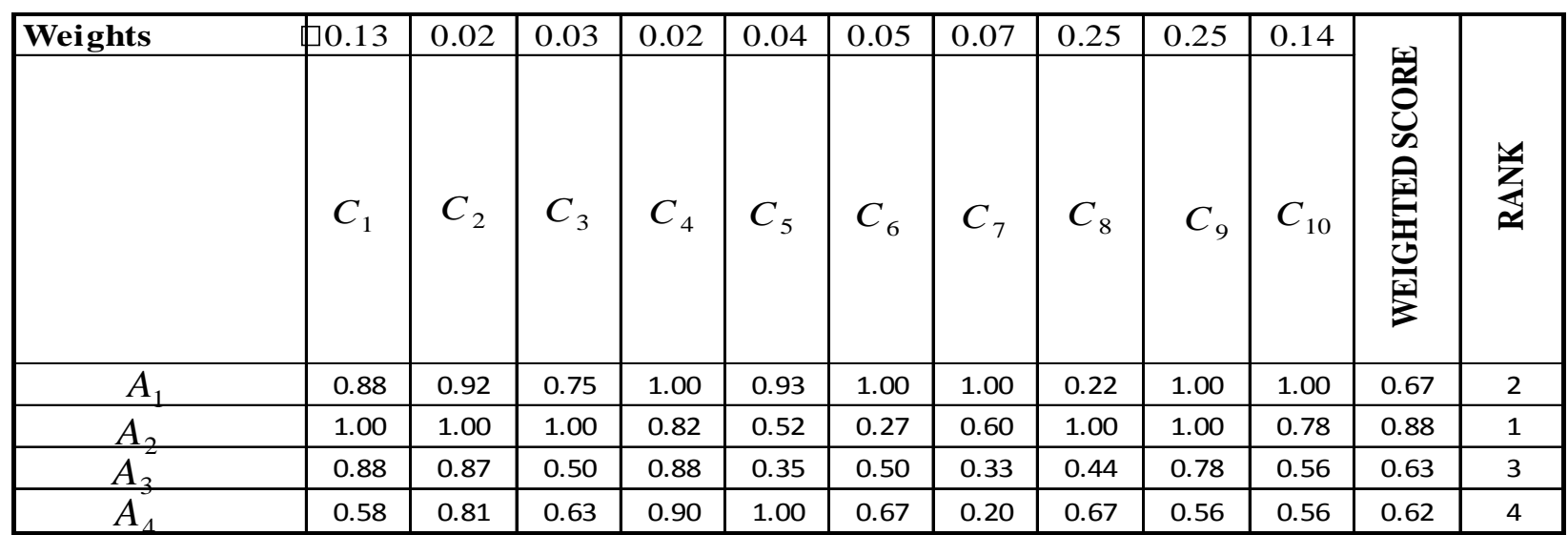

\section{Application using Elimination ET Choice Translating Reality Method}

The aggregate dominance matrixis calculated as shown in table (11).

Table 11. Aggregate dominance matrix

\begin{tabular}{|c|c|c|c|c|c|}
\hline Alternatives & $A_{1}$ & $A_{2}$ & $A_{3}$ & $A_{4}$ & \multirow{5}{*}{$\begin{array}{l}-\bar{c}=0.54 \\
\bar{d}=0.53\end{array}$} \\
\hline$A_{1}$ & 0 & 1 & 1 & 0 & \\
\hline$A_{2}$ & 0 & 0 & 1 & 0 & \\
\hline$A_{3}$ & 0 & 0 & 0 & 0 & \\
\hline$A_{4}$ & 0 & 0 & 0 & 0 & \\
\hline
\end{tabular}

The aggregate dominance matrix renders the following over ranking relationships: $A_{1} \rightarrow A_{2}, A_{1} \rightarrow A_{3}, A_{2} \rightarrow A_{3}$. We can easily see that $A_{2}$ and $A_{3}$ are dominated by $A_{1} . A_{3}$ is dominated by $A_{2}$, but we cannot tell the preference relation between $A_{1}$ and $A_{4}, A_{3}$ and $A_{4}$. Hence, $A_{2}$ and $A_{3}$ can be eliminated by ELECTRE method.

Application using Technique for Order Preference by Similarity to Ideal Solution method

As shown in table (12), $A_{2}$ is the best one. 
Military Technical College Kobry Elkobbah,

Cairo, Egypt

April 19-21,2016

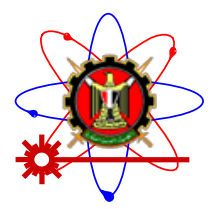

$8^{\text {th }}$ International Conference on Mathematics and Engineering Physics (ICMEP-8)

Table 12. Ranking detectors using TOPSIS method

\begin{tabular}{|c|c|c|c|c|}
\hline Alternatives & $d_{i}^{+}$ & $d_{i}^{-}$ & $c_{i}$ & Rank \\
\hline$A_{1}$ & 0.15 & 0.12 & 0.44 & 2 \\
\hline$A_{2}$ & 0.04 & 0.19 & 0.81 & 1 \\
\hline$A_{3}$ & 0.13 & 0.09 & 0.41 & 3 \\
\hline$A_{4}$ & 0.14 & 0.09 & 0.38 & 4 \\
\hline
\end{tabular}

\section{Application using Analytic Hierarchy Process}

The first step in AHP is to develop a graphical representation of our problem in terms of the overall goal, criteria, and decision alternatives. Figure (1) shows in the first level the overall goal is to select the best mine detector.

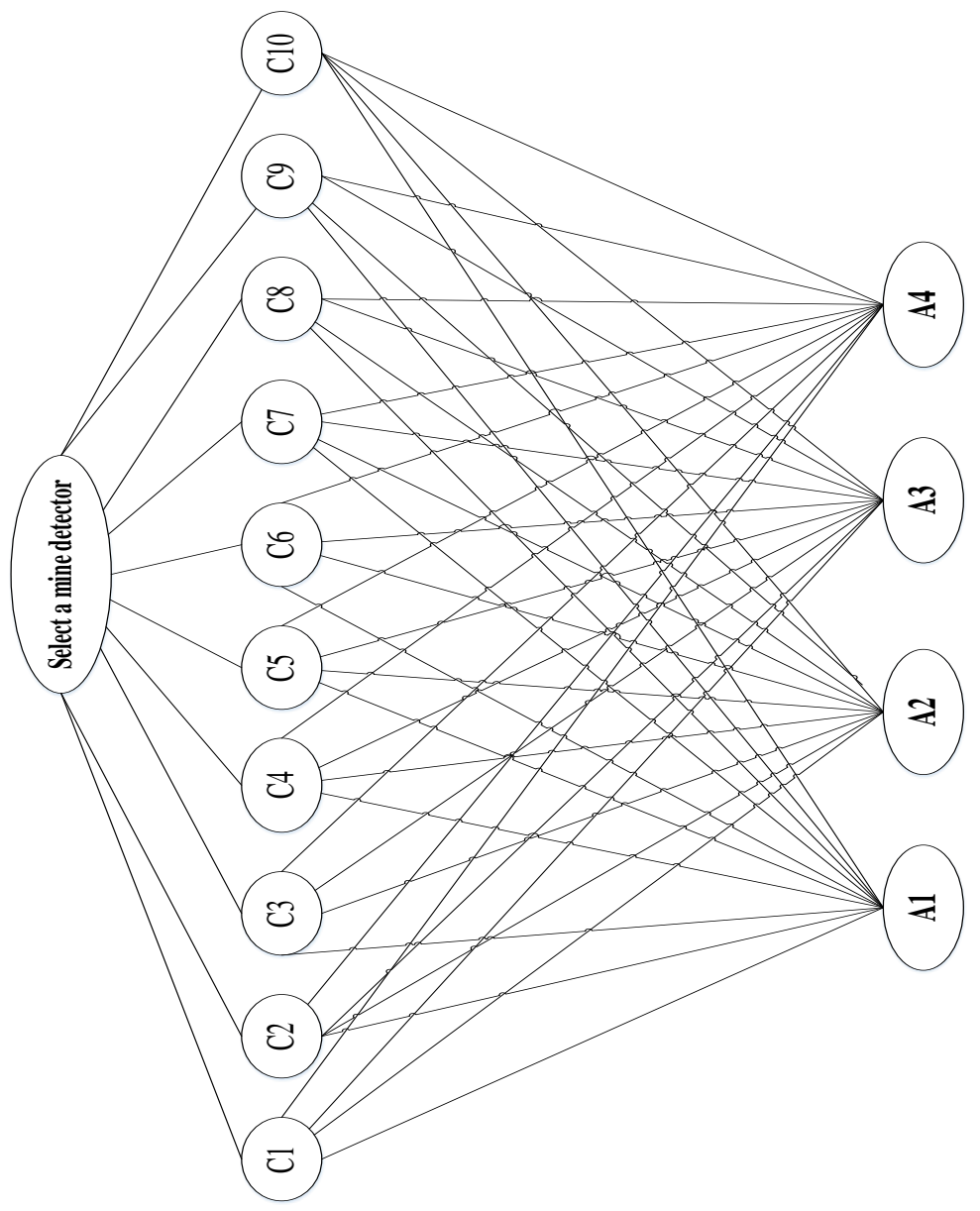

Fig. (1) Hierarchical representation of mine detector selection 
Military Technical College

Kobry Elkobbah,

Cairo, Egypt

April 19-21,2016

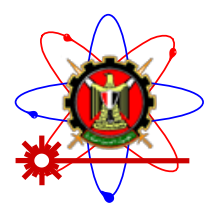

$8^{\text {th }}$ International Conference on Mathematics and Engineering Physics (ICMEP-8)

Step 2, we will show how AHP utilizes pairwise comparisons to establish priority measures for both out ten criteria and the four alternatives. AHP requires the decision maker to provide judgments about the relative importance of each criterion and then specify a preference on each criterion for each decision alternative. Step 3, various calculations are done to determine the priority of each of the decision elements using the pairwise comparison information. Step 4, consistency check of judgments. The results obtained from steps (2, 3 and 4) are summarized in table (13) as an example of the alternatives with respect to $C_{1}$.

Table 13. Pairwise comparison matrices of alternatives with respect to $C_{1}$

\begin{tabular}{|c|c|c|c|c|c|c|}
\hline \multicolumn{9}{|c|}{$C_{1}$} \\
\hline Alternatives & $A_{1}$ & $A_{2}$ & $A_{3}$ & $A_{4}$ & Weight & CR \\
\hline$A_{1}$ & 1 & $1 / 2$ & 1 & 4 & 0.235 & \\
\hline$A_{2}$ & 2 & 1 & 2 & 6 & 0.462 & \multirow{2}{*}{0.01} \\
\hline$A_{3}$ & 1 & $1 / 2$ & 1 & 4 & 0.235 & \\
\hline$A_{4}$ & $1 / 4$ & $1 / 6$ & $1 / 4$ & 1 & 0.068 & \\
\hline
\end{tabular}

Step 5 , the computation of the overall priority for the four alternatives is

$\left[\begin{array}{llllllllll}0.24 & 0.23 & 0.28 & 0.64 & 0.44 & 0.67 & 0.60 & 0.07 & 0.39 & 0.58 \\ 0.46 & 0.59 & 0.51 & 0.06 & 0.08 & 0.06 & 0.23 & 0.59 & 0.39 & 0.22 \\ 0.24 & 0.11 & 0.11 & 0.18 & 0.05 & 0.11 & 0.11 & 0.11 & 0.14 & 0.10 \\ 0.07 & 0.07 & 0.10 & 0.13 & 0.44 & 0.15 & 0.06 & 0.23 & 0.07 & 0.10\end{array}\right]\left[\begin{array}{l}0.13 \\ 0.02 \\ 0.03 \\ 0.02 \\ 0.04 \\ 0.05 \\ 0.07 \\ 0.25 \\ 0.25 \\ 0.14\end{array}\right]=\left[\begin{array}{l}0.34 \\ 0.39 \\ 0.13 \\ 0.14\end{array}\right]$

The output of AHP is a prioritized ranking indicating the overall preferences, which can be summarized in table (14). $A_{2}$ is the best one. 
Military Technical College Kobry Elkobbah,

Cairo, Egypt

April 19-21,2016

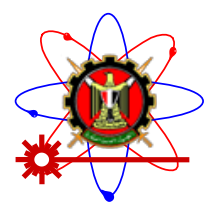

$8^{\text {th }}$ International Conference on Mathematics and Engineering Physics (ICMEP-8)

Table 14. Ranking alternatives using AHP method

\begin{tabular}{|c|c|c|}
\hline Alternatives & Weights & Rank \\
\hline$A_{1}$ & 0.35 & 2 \\
\hline$A_{2}$ & 0.38 & 1 \\
\hline$A_{3}$ & 0.13 & 4 \\
\hline$A_{4}$ & 0.14 & 3 \\
\hline
\end{tabular}

\section{Comparative Analysis}

The outcomes from different studies related to the problem of the selection of mine detector for armyare summarized in table (15) and figure (2).

Table (15) Results of the seven methods

\begin{tabular}{|c|c|c|c|c|c|c|c|}
\hline & Max-Min & Max-Max & SAW & WPM & ELECTRE & TOPSIS & AHP \\
\hline$A_{1}$ & - & 1 & 2 & 2 & 1 & 2 & 2 \\
\hline$A_{2}$ & - & 1 & 1 & 1 & - & 1 & 1 \\
\hline$A_{3}$ & 1 & - & 3 & 3 & - & 3 & 4 \\
\hline$A_{4}$ & - & 1 & 4 & 4 & 1 & 4 & 3 \\
\hline
\end{tabular}


Military Technical College

Kobry Elkobbah,

Cairo, Egypt

April 19-21,2016

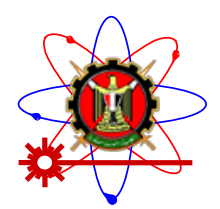

$8^{\text {th }}$ International Conference on Mathematics and Engineering Physics (ICMEP-8)

\section{Results of the seven methods}

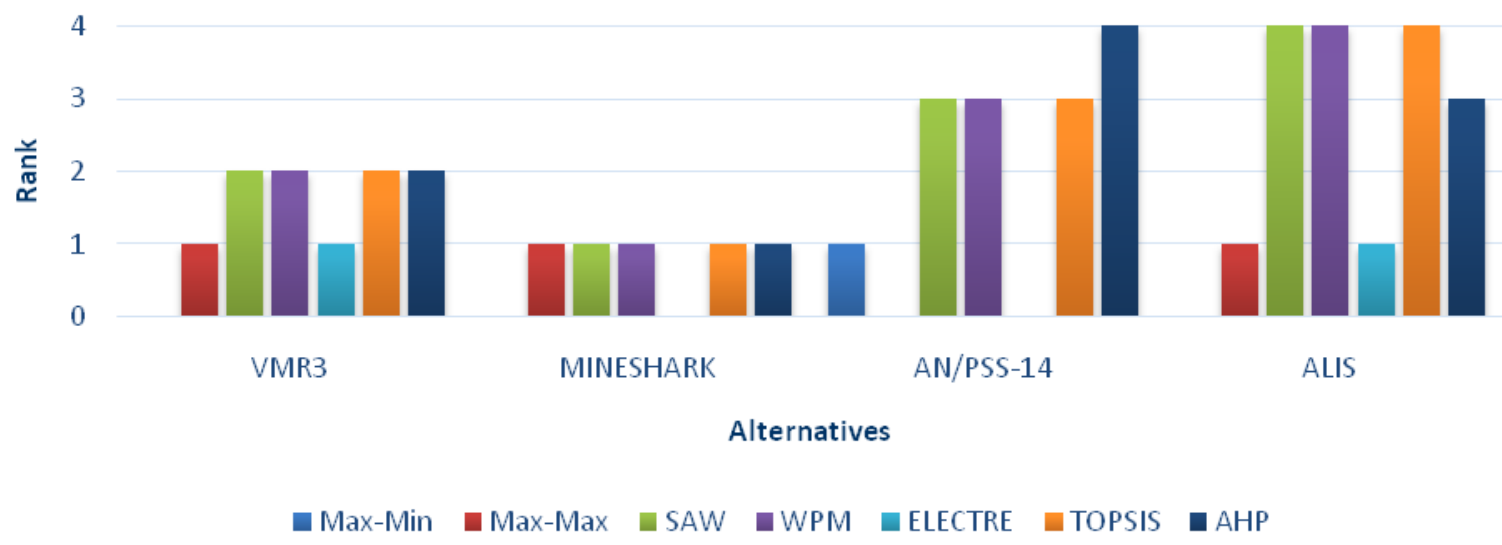

Fig. (2) Results obtained by the seven methods

As can be seen, the outputs are different when different methods are applied. Max-Min, MaxMax, and ELECTRE methods are not outranking methods in this problem. SAW, WPM and TOPSIS methods give the same rank and differ from AHP rank. As shownfive methods give, that $A_{2}$ is the best one to be selected. The agreement is equal $71 \%$.

Correlation analysis tells us the degree of relation between our methods. In this paper, Spearman's correlation test is used to finding the correlation between the different ranks of the methods[17].Max-Min, Max-Maxand ELECTRE methods are eliminated. The other methods show some variations summarized in table (16) and figure (3).

Table 16. Rankings of different methods

\begin{tabular}{|c|c|c|c|c|}
\hline & SAW & WPM & TOPSIS & AHP \\
\hline$A_{1}$ & 2 & 2 & 2 & 2 \\
\hline$A_{2}$ & 1 & 1 & 1 & 1 \\
\hline$A_{3}$ & 3 & 3 & 3 & 4 \\
\hline$A_{4}$ & 4 & 4 & 4 & 3 \\
\hline
\end{tabular}


Military Technical College

Kobry Elkobbah,

Cairo, Egypt

April 19-21,2016

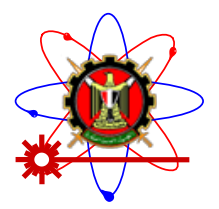

$8^{\text {th }}$ International Conference on Mathematics and Engineering Physics (ICMEP-8)

\section{Results of different techniques}

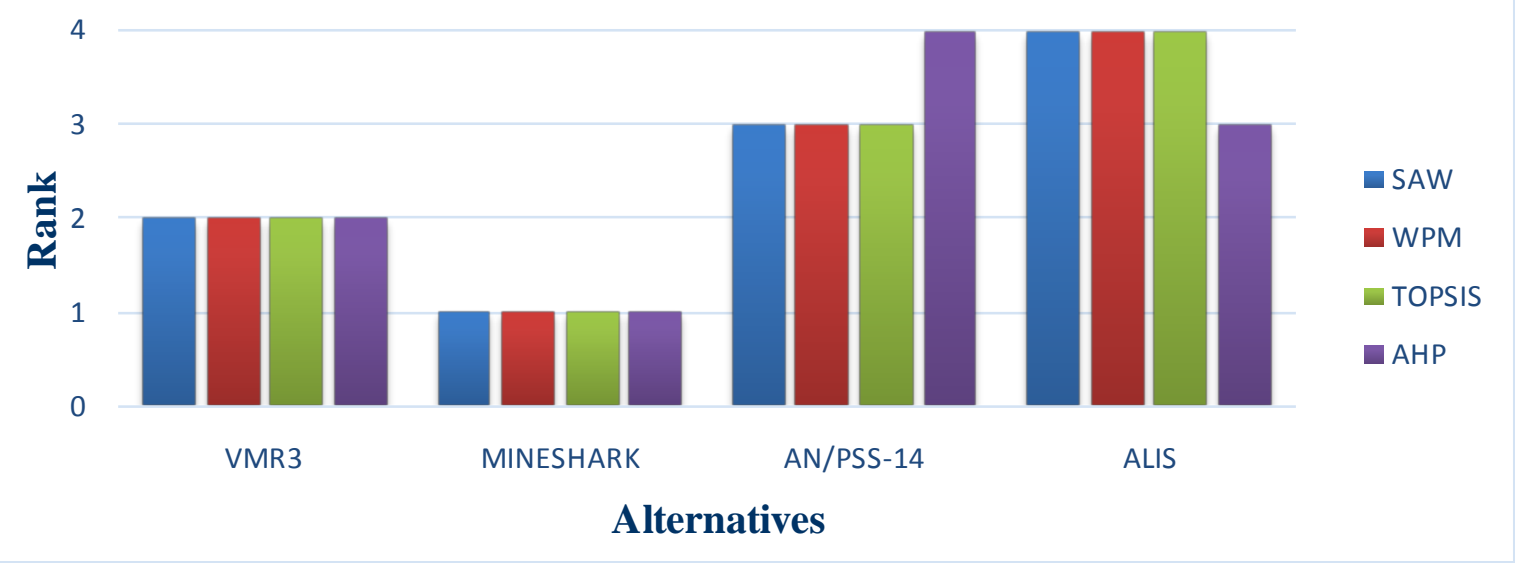

Fig. (3) Comparison between results of four methods

There are three methods from four have the same outranking so the agreement is $75 \%$. Using an excel sheet $r_{s}$ between the five methods is calculated, results are summarized in table (17).

Table 17. Spearman's rank correlation coefficient between MCDM methods

\begin{tabular}{|c|c|c|c|c|}
\hline & SAW & WPM & TOPSIS & AHP \\
\hline SAW & 1 & & \multicolumn{2}{|l}{} \\
\cline { 1 - 3 } WPM & 1 & 1 & 1 & \\
\hline TOPSIS & 1 & 1 & 0.8 & 1 \\
\hline AHP & 0.8 & 0.8 & & \\
\hline
\end{tabular}

We can summarize that SAW, WPM, and TOPSIS are perfectly correlated with each other. AHP are strongly correlated with SAW, WPM, and TOPSIS. That means any method of them is used in our case study gives nearly the same ranking.

\section{Conclusion}

The Need for an up-to-date mine detector for the hidden mines is an issue ofupmost importance in army during the war against terrorist.Problems for MCDM are common occurrences in everyday life. MCDM refersto making decisions in the presence of multiple, usually conflicting criteriafor judging the alternatives.Seven discrete MCDM methods are chosen to deal with the problem ofselecting mine detector. Four methods give that $A_{2}$ is the best one.Using Spearman's correlation test gives that any method used in our case studygives nearly the same ranking, eliminating Max-Min, Max-Max, andELECTRE methods. 
Military Technical College

Kobry Elkobbah,

Cairo, Egypt

April 19-21,2016

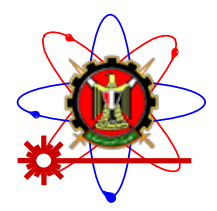

\section{References}

[1] R. Mohanty, "Project selection by a multiple-criteria decision-making method: an example from a developing country," International Journal of Project Management, vol. 10, pp. 31-38, 1992.

[2] M. Janic and A. Reggiani, "An application of the multiple criteria decision making (MCDM) analysis to the selection of a new hub airport," European journal of transport and infrastructure research EJTIR, 2 (2), 2002.

[3] N. Caterino, I. Iervolino, G. Manfredi, and E. Cosenza, "Selection of the "best" seismic upgrading solution for a RC building by MCDM," in Proceedings of the Second International fib Congress, Napoli, 2006.

[4] P. Yanpirat and V. Panjarongkha, "Decision Support Model for site selection of Wafer Fabrication Plant in Thailand-The MCDM Approach," ed: Bangkok, 2005.

[5] G. Yang, W. J. Huang, and L. L. Lei, "Using AHP and TOPSIS approaches in nuclear power plant equipment supplier selection," in Key Engineering Materials, 2010, pp. 761-764.

[6] K. R. Gaurh, I. Khan, and M. Ghosh, "MCDM Techniques for the Selection of Material Handling Equipment in the Automobile Industry."

[7] A. Kahriman, M. Oztokatli, and G. S. Das, "Selection of a communication satellite manufacturer using MCDM methods," in Recent Advances in Space Technologies (RAST), 2015 7th International Conference on, 2015, pp. 347-351.

[8] D. S. Resobowo, K. A. Buda, and A. Dinariyana, "Using Sensitivity Analysis for Selecting of Ship Maintenance Variables for Improving Reliability of Military Ship," Academic Research International, vol. 5, p. 127, 2014.

[9] T.-H. Chang and T.-C. Wang, "SELECTION OF INITIAL TRAINING AIRCRAFT BY UTILIZING ENTROPY-BASED TOPSIS APPROACH."

[10] M. Dağdeviren, S. Yavuz, and N. Kilınç, "Weapon selection using the AHP and TOPSIS methods under fuzzy environment," Expert Systems with Applications, vol. 36, pp. 8143-8151, 2009.

[11] A. R. Ravindran, Operations Research and Management Science Handbook: CRC Press, 2007.

[12] C.-L. Hwang and K. Yoon, Lecture notes in economics and mathematical systems vol. $164,1981$.

[13] V. M. Athawale and S. Chakraborty, "Material selection using multi-criteria decisionmaking methods: a comparative study," Proceedings of the Institution of Mechanical Engineers, Part L: Journal of Materials Design and Applications, vol. 226, pp. 266285, 2012.

[14] J. D. Camm and J. R. Evans, Management Science: Modeling, Analysis, and Interpretation: South-Western College Pub., 1996.

[15] S. A. Ltd., "AHP Prioritization," www.scbuk.com/ahp.html, Ed., ed, 2012.

[16] J. Jablonský, "Software support for multiple criteria decision making problems," Management, vol. 4, pp. 029-034, 2009.

[17] S. M. Ross, INTRODUCTION TO PROBABILITY AND STATISTICS FOR ENGINEERS AND SCIENTISTS, Fourth ed., 2009. 